\title{
Inducing salt tolerance in sweet corn by magnetic priming
}

\author{
Soheil KARIMI ${ }^{1}$, Saeid ESHGHI ${ }^{2}$, Saeed KARIMI ${ }^{3}$, Saman HASAN-NEZHADIAN $^{4}$
}

Received October 14, 2016; accepted December 27, 2016.

Delo je prispelo 14. oktobra 2016, sprejeto 27. decembra 2016.

\begin{abstract}
This study evaluates seed germination and growth of sweet corn under $\mathrm{NaCl}$ stress $(0,50$, and $100 \mathrm{mM})$, after exposing the seeds to weak $(15 \mathrm{mT})$ or strong $(150 \mathrm{mT})$ magnetic fields (MF) for different durations $(0,6,12$, and 24 hours). Salinity reduced seed germination and plant growth. MF treatments enhanced rate and percentage of germination and improved plant growth, regardless of salinity. Higher germination rate was obtained by the stronger MF, however, the seedling were more vigorous after priming with $15 \mathrm{mT}$ MF. Proline accumulation was observed in parallel with the loss of plant water content under $100 \mathrm{mM} \mathrm{NaCl}$ stress. MF prevented proline accumulation by improving water absorption. Positive correlation between $\mathrm{H}_{2} \mathrm{O}_{2}$ accumulation and membrane thermostability (MTI) was found after MF treatments, which revealed that MF primed the plant for salinity by $\mathrm{H}_{2} \mathrm{O}_{2}$ signaling. However, over-accumulation of $\mathrm{H}_{2} \mathrm{O}_{2}$ after prolonged MF exposure adversely affected MTI under severe salt stress. In conclusion, magnetic priming for 6 hours was suggested for enhancing germination and growth of sweet corn under salt stress.
\end{abstract}

Key words: hydrogen peroxide; maize; malondialdehyde; plant water content; proline; seed germination; seedling growth

Abbreviations: DM: dry mass, FM: fresh mass, MDA: malondialdehyde, MF: magnetic field, MGT: mean germination time, MTI: membrane thermostability index, PWC: plant water content, ROS: reactive oxygen species.

\section{IZVLEČEK}

\section{INDUKCIJA TOLERANCE NA SOL SLADKE KORUZE S PREDHODNIM OBRAVNAVANJEM SEMEN Z MAGNETNIM POLJEM}

$\mathrm{V}$ raziskavi sta bili ovrednoteni kalitev in rast sladke koruze $\mathrm{v}$ razmerah solnega stresa $(\mathrm{NaCl} ; 0,50$, in $100 \mathrm{mM})$, po izpostavitvi semen šibkemu (15 mT) in močnemu (150 mT) magnetnemu polju (MF) v trajanju 0, 6, 12, in 24 ur. Slanost je zmanjšala kalitev semen in rast rastlin. Obravnavanje $\mathrm{Z}$ magnetnim poljem je povečalo hitrost in odstotek kalitve ter izboljšalo rast rastlin, ne glede na slanost. Kalitev je bila značilno večja pri obravnavanju z močnejšim magnetnim poljem, kalice so bile bolj vitalne pri obravnavanju z $15 \mathrm{mT}$ MF. Akumulacija prolina je bila opažena sočasno z izgubo vsebnosti vode $\mathrm{v}$ razmerah močnega $\mathrm{NaCl}$ stresa. Obravnavanje $\mathrm{z}$ magnetnim poljem je izboljšalo absorbcijo vode in preprečilo akumulacijo prolina. Pozitivna korelacija med akumulacijo $\mathrm{H}_{2} \mathrm{O}_{2}$ in termostabilnostjo membran (MTI), ki je bila opažena po obravnavanju z MF je pokazala, da so bile tako obravnavane rastline odpornejše na slanost preko $\mathrm{H}_{2} \mathrm{O}_{2}$ signalizacije. Kljub temu je prekomerna akumulacija $\mathrm{H}_{2} \mathrm{O}_{2}$, kot posledica podaljšane izpostavitve $\mathrm{MF}$, negativno vplivala na MTI v razmerah solnega stresa. Zaključimo lahko, da predobravnavanje semen $\mathrm{z}$ magnetnim poljem za 6 ur pospeši nihovo kalitev in rast rastlin $\mathrm{v}$ razmerah solnega stresa.

Ključne besede: vodikov peroksid; koruza; malondialdehid; vsebnost vode; prolin; kalitev; rast kalic

Abbreviations: DM: dry mass, FM: fresh mass, MDA: malondialdehyde, MF: magnetic field, MGT: mean germination time, MTI: membrane thermostability index, PWC: plant water content, ROS: reactive oxygen species.

\footnotetext{
1 PhD, Department of Horticulture, College of Abouraihan, University of Tehran - Tehran, Iran, corresponding author: skarimi@ut.ac.ir

$2 \mathrm{PhD}$, Department of Horticultural Science, College of Agriculture, Shiraz University - Shiraz, Iran

$3 \mathrm{PhD}$, Department of Materials Science and Engineering, Engineering School, Shiraz University -Shiraz, Iran

4 MSc, Department of Crop Science, College of Agriculture, Shiraz University - Shiraz, Iran
} 


\section{INTRODUCTION}

Salinity was always known to be a constraint to agricultural production. In the $21^{\text {st }}$ century, however, it is predicted that enhanced soil salinization due to climate change and warming of the planet will be the major challenge in agriculture. The deleterious effects of salt stress on plant are associated with low osmotic potential of soil solution (osmotic stress), nutritional imbalance, specific ion effect (salt stress), and interactions among these factors (Ashraf, 2004). Most of the plant species exhibit over-sensitive responses to salt stress at seed germination and early growth stages of seedling (Cuartero et al., 2006). Seed germination may be delayed or prevented by salt stress (Lin et al., 2011). Several strategies can be employed to overcome the adverse effects of salinity. In addition to the use of the classic breeding and plant genetic transformation of crops, employing seed presowing treatments as a valuable strategy may facilitate seed germination and seedling growth under abiotic stress such as salinity (Iqbal and Ashraf, 2010).

Magnetic field (MF) treatments have shown to enhance seed germination, plant vigor and productivity (Vashisth and Nagarajan, 2010; Radhakrishnan and Kumari, 2012), and delay the senescence process in plant organs (Piacentini et al., 2001). Such effects may be due to promotion of gene expression, protein biosynthesis, enzymes activity, cell reproduction and overall metabolism of plant (Stange et al., 2002; Atak et al., 2007;
Vashisth and Nagarajan, 2010). Rapid germination and vigor of seedlings is linked with enhancement of activities of $\alpha$-amylase, dehydrogenase and protease in seeds following MF exposure (Vashisth and Nagarajan, 2010; Radhakrishnan and Kumari, 2012). Seeds that have been treated by MF for a short time generate more extensive root system as well as more vigorous shoot compared to untreated seeds (Florez et al., 2007; Vashisth and Nagarajan, 2010). Therefore, MF may improve germination parameters and initial growth of non-standard seeds (Aladjadjiyan, 2002).

In spite of the positive effects of MF on plant, there are limited numbers of studies that examine the effects of MF treatments on plant responses to environmental stresses. It has shown that magnetic and electromagnetic treatments enhance the salinealkali tolerance (Xi et al., 1994), enhance seed germination and seedling growth under heat stress (Ružič and Jerman, 2002; Cakmak et al., 2010), and improve plant osmotic tolerance (Karimi et al., 2012). In contrast, Yao et al. (2005) showed that MF treatments enhanced sensitivity of cucumber seedlings to UV irradiation. Therefore, the current study was conducted to investigate whether the benefits of pre-sawing MF exposure would improve sweet corn seed germination and vigor under salt stress, and to determine the effects of MF intensity and exposure duration on plant responses to abiotic stress.

\section{MATERIAL AND METHODS}

Uniform seeds of sweet corn (Zea mays var. saccharata 'SC 404') were selected and disinfected with $0.3 \%$ fungicide Benomyl (GYAH Corp., Iran) for $15 \mathrm{~min}$ and thoroughly washed with sterilized distilled water. The seeds were soaked for 3 hours (h) in distilled water and then air dried prior to starting the experiment. Twentyfive seeds were placed between two Whatman No. 1 filter papers laid in the Petri dishes and incubated at $30 / 25^{\circ} \mathrm{C}$ day/night temperature, $12 \mathrm{~h}$ photoperiod with light intensity of $30 \mathrm{~W} \mathrm{~m}^{-2}$. Salt treatments were applied by adding $\mathrm{NaCl}$ solutions to the Petri dishes ( 0 - control, 50 and $100 \mathrm{mM}$ ).
The Petri dishes were irrigated with $5 \mathrm{ml}$ salt solution of the respective treatment every 24 hours. The filter beds were changed every 48 hours to avoid salt accumulation.

The MF treatments were induced using two cubic magnets for each Petri dish. The geometric characteristics of the magnets were $100 \mathrm{~mm}$ length, $30 \mathrm{~mm}$ width and $20 \mathrm{~mm}$ thickness (Figure 1). They were arranged at 0 , and $5.5 \mathrm{~cm}$ apart from bottom and top of the Petri dishes to generate 150 and $15 \mathrm{mT}$ magnetic fields, respectively. The intensity of magnetic fields was provided by the 
Department of Materials Science and Engineering, Engineering School of Shiraz University. The seeds were exposed to the strong and weak magnetic fields for different durations $(0,6,12$, and $24 \mathrm{~h}$ ). The Petri dishes were kept at least $100 \mathrm{~cm}$ apart, to avoid the influence of the magnets on each other.

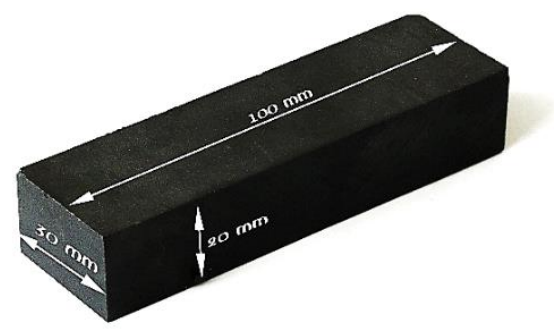

Figure 1: The geometric characteristics of the magnets used in the experiments $(100 \times 30 \times 20 \mathrm{~mm})$.

Seed germination was evaluated according to the guidelines issued by the International Seed Testing Association (ISTA, 2004). The number of germinated seeds was recorded every 6 hours for a period of 5 days. A seed was considered germinated when its seminal root had emerged $\geq$ $2.0 \mathrm{~mm}$. Total germination was recorded as overall percentage of germinated seeds. The germination rate was determined by measuring the length of time required for maximum germination percentage, and by calculating mean germination time (MGT) using the following formula (Eq. 1):

$M G T=\sum_{i=1}^{n} N_{i} T i / \sum_{i=1}^{n} N_{i}$

In this formula: $T i$ is the initial time and $N i$ is the number of germinated seeds between $T i-1$ and $T i$.

To evaluate the early growth of the plant in response to the $\mathrm{MF}$ and the $\mathrm{NaCl}$ stress, another experiment was conducted under the same conditions as described above. Ten uniform and sterilized seeds were subjected to 0,50 and $100 \mathrm{mM} \mathrm{NaCl}$, after exposing to the magnetic treatments as describe in the first experiment. After 7 days, the seedlings were harvested and length, fresh and dry mass of root and shoot were measured. Dry mass was measured after drying at $70{ }^{\circ} \mathrm{C}$ for 72 hours. Plant water content was calculated according to fresh and dry mass of the seedlings.

Proline was measured in $200 \mathrm{mg}$ of dried shoot tissue using the method described by Bates et al. (1973). The plant material was homogenized in
$3 \%$ sulfosalicylic acid and the extract was reacted with glacial acetic acid and ninhydrin in boiling water. The reaction mixture was extracted with toluene. The absorbance was measured at $520 \mathrm{~nm}$ by spectrophotometry (Shimadzu model 160 A). Lproline was used as standard.

The membrane thermostability index (MTI) was assessed by measuring electrolyte leakage derived from the shoot tissue by adopting an electrical conductivity meter (Ohm 419). MTI was applied to find out changes in cell membrane permeability according to the technique of Arora et al (1998) with slight modifications. Concentration of hydrogen peroxide $\left(\mathrm{H}_{2} \mathrm{O}_{2}\right)$ was determined in plant tissues according to the method described by Velikova et al. (2000). Shoot and root tissue was homogenized in trichloroacetic acid (TCA) and centrifuging, the supernatant was added to potassium phosphate buffer and KI. The absorbance was measured spectrophotometrically at $390 \mathrm{~nm}$ (Shimadzu model 160 A). Lipid peroxidation was determined by calculating the quantity of malondialdehyde (MDA) using the thiobarbituric acid reactive substances method explained by Heath and Parker (1968). Shoots and roots of the plants were homogenized in TCA and after centrifuging, the supernatant was mixed with thiobarbituric acid (TBA) in $20 \%$ TCA. The mixture was then heated up at $95{ }^{\circ} \mathrm{C}$ for 30 minutes. After cooling and centrifugation at 10,000 $\times \mathrm{g}$ for 10 minutes, the supernatant absorbance was verified at 532 and $600 \mathrm{~nm}$. MDA content ( $\mathrm{nmol} \mathrm{g}^{-}$ 1 FM) was calculated according to extinction coefficient of $155 \mathrm{mM} \mathrm{cm}^{-1}$, after withdrawing the non-specific absorbance at $600 \mathrm{~nm}$. 
The treatments were arranged as a factorial experiment based on a completely randomized design comprising 3 factors $(\mathrm{NaCl}$ levels, $\mathrm{MF}$ intensities and MF exposure durations) with 4 replications. The data were subjected to an analysis of variance (ANOVA) and Duncan's multiple range test (DMRT) at $P \leq 0.05$ was used for comparing the means. Spearman bivariate correlation test was used to investigate the correlation between the measured parameters. The statistical analyses were performed by SPSS ( $\mathrm{v}$ 21.0).

\section{RESULTS}

Salinity treatments did not affect germination percentage during the first 24-h after incubation (Table 1). At this stage, the highest germination percentage was observed in $150 \mathrm{mT}(28.6 \%)$, and the control treatment had the lowest value $(4.7 \%)$. The highest germination percentage was found in the 6-h MF exposure treatment $(25.3 \%)$. Salt stress induced by $100 \mathrm{mM} \mathrm{NaCl}$ significantly reduced germination percentage at 48-h stage. Magnetic exposure enhanced seed germination, however, no significant difference was observed between 15 and $150 \mathrm{mT}$ intensities and the highest seed germination was observed in the 6-h and 12-h MF exposure durations. After 72-h hours, the adverse effects of $50 \mathrm{mM} \mathrm{NaCl}$ stress became evident on seed germination. Effects of magnetic exposure on enhancing seed germination was significant at this stage, however, no significant difference was observed between 15 and $150 \mathrm{mT}$ intensities (79.0 and $82.5 \%$, respectively). Seeds exposed to MF for either 6 or 12 hours showed the highest germination at this stage (86.0 and $81.5 \%$, respectively). Final germination percentage was significantly reduced under salt stress and no significant difference was found between 50 and
$100 \mathrm{mM} \mathrm{NaCl}$ treatments. The highest percentage of germinated seeds was obtained in the 6-h magnetic treatment $(89.5 \%)$.

The time required for maximum germination percentage was significantly increased by 50 and $100 \mathrm{mM} \mathrm{NaCl}$ treatments $(78.6$ and $77.2 \mathrm{~h}$, respectively) when compared to the control (68.6 h). MF exposure significantly reduced the time for max germination. A significant interaction effect of $\mathrm{NaCl}$ stress and $\mathrm{MF}$ exposure duration on the time required for max germination was detected (Figure 2). The interaction effect showed that by increasing $\mathrm{NaCl}$ concentration in medium, time for maximum germination of non-magnetic treated seeds significantly increased, however, the time was reduced to the control level in the 6-h and 12-h magnetic treated seeds. MGT, indicating overall seed germination rate, was significantly reduced by application of $100 \mathrm{mM} \mathrm{NaCl}(72.7 \mathrm{~h})$. MGT of the non-MF treated seeds was $75 \mathrm{~h}$. The time was significantly reduced to 72.6 and $69.1 \mathrm{~h}$ by 15 and $150 \mathrm{mT}$ MF intensities, respectively. The lowest MGT was found in 6-h and 12-h MF exposure durations (69.7 and $70.9 \mathrm{~h}$, respectively). 
Table 1: Effects of salinity stress and magnetic treatments on seed germination of Zea mays var. saccharata

\begin{tabular}{|c|c|c|c|c|c|c|}
\hline & $\begin{array}{l}\text { Germination } \\
{[\%]-24 \mathrm{~h}}\end{array}$ & $\begin{array}{l}\text { Germination } \\
{[\%]-48 \mathrm{~h}}\end{array}$ & $\begin{array}{l}\text { Germination } \\
{[\%]-72 \mathrm{~h}}\end{array}$ & $\begin{array}{l}\text { Max } \\
\text { germination [\%] }\end{array}$ & $\begin{array}{l}\text { Time to } \max \\
\text { germination }[\mathrm{h}]\end{array}$ & $\begin{array}{l}\text { MGT } \\
{[\mathrm{h}]}\end{array}$ \\
\hline \multicolumn{7}{|l|}{$\mathrm{NaCl}[\mathrm{mM}]$} \\
\hline 0 & 18.0 & $65.8^{\mathrm{a}^{\dagger}}$ & $86.5^{\mathrm{a}}$ & $89.7^{\mathrm{a}}$ & $68.6^{\mathrm{b}}$ & $70.9^{\mathrm{b}}$ \\
\hline 50 & 18.7 & $62.6^{\mathrm{a}}$ & $78.9^{\mathrm{b}}$ & $84.2^{\mathrm{b}}$ & $78.6^{\mathrm{a}}$ & $71.0^{\mathrm{b}}$ \\
\hline 100 & 14.3 & $50.3^{\mathrm{b}}$ & $73.4^{\mathrm{b}}$ & $80.7^{\mathrm{b}}$ & $77.2^{\mathrm{a}}$ & $72.7^{\mathrm{a}}$ \\
\hline \multicolumn{7}{|c|}{ MF Intensity [mT] } \\
\hline 0 & $4.7^{\mathrm{c}}$ & $49.3^{\mathrm{b}}$ & $72.0^{\mathrm{b}}$ & 82.7 & $84.5^{\mathrm{a}}$ & $75.0^{\mathrm{a}}$ \\
\hline 15 & $10.7^{\mathrm{b}}$ & $60.6^{\mathrm{a}}$ & $79.0^{\mathrm{a}}$ & 83.8 & $73.8^{\mathrm{b}}$ & $72.6^{\mathrm{b}}$ \\
\hline 150 & $28.6^{\mathrm{a}}$ & $63.7^{\mathrm{a}}$ & $82.5^{\mathrm{a}}$ & 87.4 & $70.3^{\mathrm{b}}$ & $69.1^{\mathrm{c}}$ \\
\hline \multicolumn{7}{|c|}{ MF Exposure Duration [h] } \\
\hline 0 & $4.7^{\mathrm{d}}$ & $49.3^{\mathrm{b}}$ & $72.0^{\mathrm{b}}$ & $82.7^{\mathrm{b}}$ & $84.5^{\mathrm{a}}$ & $75.0^{\mathrm{a}}$ \\
\hline 6 & $25.3^{\mathrm{a}}$ & $67.0^{\mathrm{a}}$ & $86.0^{\mathrm{a}}$ & $89.5^{\mathrm{a}}$ & $71.7^{\mathrm{b}}$ & $69.7^{\mathrm{c}}$ \\
\hline 12 & $19.0^{\mathrm{b}}$ & $64.5^{\mathrm{a}}$ & $81.5^{\mathrm{a}}$ & $86.5^{\mathrm{ab}}$ & $70.8^{\mathrm{b}}$ & $70.9^{\mathrm{c}}$ \\
\hline 24 & $11.8^{\mathrm{c}}$ & $53.2^{\mathrm{b}}$ & $72.8^{\mathrm{b}}$ & $80.8^{\mathrm{b}}$ & $73.8^{\mathrm{b}}$ & $72.4^{\mathrm{b}}$ \\
\hline \multicolumn{7}{|l|}{ ANOVA } \\
\hline $\mathrm{NaCl}$ & ns & $* *$ & $* *$ & $* *$ & $* *$ & $* *$ \\
\hline Intensity & $* *$ & $*$ & $*$ & ns & $* *$ & $* *$ \\
\hline Duration & $* *$ & $* *$ & $* *$ & ** & * & ** \\
\hline $\mathrm{NaCl} \times$ Int. & ns & ns & ns & $\mathrm{ns}$ & $\mathrm{ns}$ & $\mathrm{ns}$ \\
\hline $\mathrm{NaCl} \times$ Dur. & ns & ns & ns & ns & $*$ & ns \\
\hline Int. $\times$ Dur. & $\mathrm{ns}$ & ns & ns & ns & ns & ns \\
\hline $\mathrm{NaCl} \times$ Int. $\times$ Dur. & $\mathrm{ns}$ & $\mathrm{ns}$ & $\mathrm{ns}$ & ns & ns & ns \\
\hline
\end{tabular}

** and *: Significant at 0.01 and 0.05 levels, respectively; ns: Non-significant.

${ }^{\dagger}$. Means separation by DMRT $(P \unlhd 0.05)$.

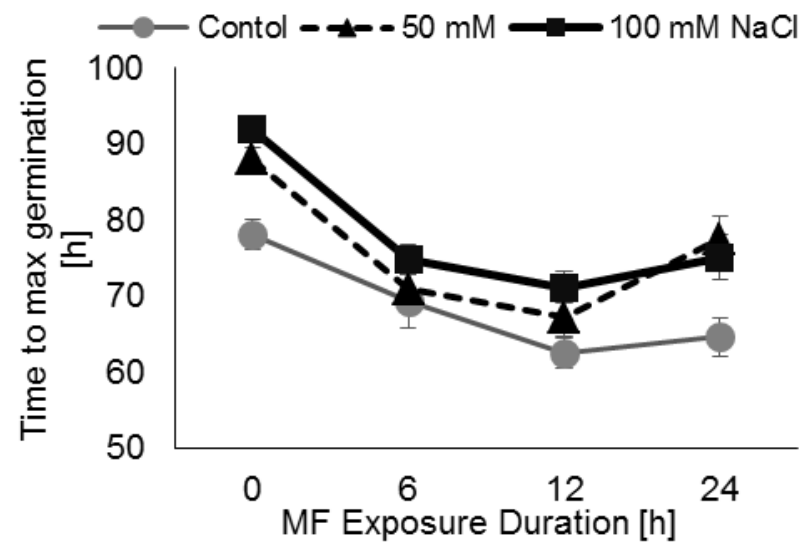

Figure 2: The interaction effect of magnetic field exposure duration and $\mathrm{NaCl}$ concentration in medium on time required for maximum seed germination percentage of Zea mays var. saccharata (Data are means $\pm \mathrm{SEM}$ of four independent samples).

Table 2 represents the effects of MF treatments and $\mathrm{NaCl}$ stress on growth parameters of sweet corn seedlings. Salt stress significantly reduced the fresh mass (FM) of sweet corn shoot. The highest shoot FM was obtained in the control treatment (248.8 $\mathrm{mg}$ ) and the lowest FM was observed in $100 \mathrm{mM} \mathrm{NaCl}$ treatment $(216.9 \mathrm{mg})$. Magnetic exposure significantly increased the shoot FM; however, no significant differences were found between the weak and the strong MF or between the different magnetic exposure durations. Shoot dry mass (DM) was significantly affected by MF intensity and was significantly higher in $15 \mathrm{mT}$ MF.

A significant reduction in root FM was observed under $100 \mathrm{mM} \mathrm{NaCl}$ stress. Exposing to $15 \mathrm{mT}$ MF significantly increased root FM (160.1 mg) 
and the highest root FM was found in the 12-h and 24-h MF treatments (143.5 and $144.7 \mathrm{mg}$, respectively). Root DM was significantly reduced under $50 \mathrm{mM}(9.3 \mathrm{mg})$ and $100 \mathrm{mM} \mathrm{NaCl}$ stress (6.6 $\mathrm{mg}$ ) when compared to control treatment
(11.9 mg). MF treatments significantly increased root DM, however, no significant differences were found between 15 and $150 \mathrm{mT}$ intensities or between the different MF exposure durations.

Table 2: Effects of salinity stress and magnetic treatments on fresh mass (FM) and dry mass (DM) of Zea mays var. saccharata seedling

\begin{tabular}{|c|c|c|c|c|}
\hline & $\begin{array}{l}\text { Shoot FM } \\
{[\mathrm{mg}]}\end{array}$ & $\begin{array}{l}\text { Shoot DM } \\
{[\mathrm{mg}]}\end{array}$ & $\begin{array}{l}\text { Root FM } \\
{[\mathrm{mg}]}\end{array}$ & $\begin{array}{l}\text { Root DM } \\
{[\mathrm{mg}]}\end{array}$ \\
\hline \multicolumn{5}{|l|}{$\mathrm{NaCl}[\mathrm{mM}]$} \\
\hline 0 & $248.8^{\mathrm{a} \uparrow}$ & 21.2 & $143.6^{\mathrm{a}}$ & $11.9^{\mathrm{a}}$ \\
\hline 50 & $227.1^{\mathrm{ab}}$ & 19.1 & $125.4^{\mathrm{a}}$ & $9.3^{\mathrm{b}}$ \\
\hline 100 & $216.9^{b}$ & 18.0 & $100.2^{\mathrm{b}}$ & $6.6^{\mathrm{c}}$ \\
\hline \multicolumn{5}{|c|}{ MF Intensity [mT] } \\
\hline 0 & $198.9^{\mathrm{b}}$ & $16.9^{\mathrm{b}}$ & $94.7^{\mathrm{b}}$ & $6.6^{\mathrm{b}}$ \\
\hline 15 & $242.9^{\mathrm{a}}$ & $23.4^{\mathrm{a}}$ & $160.1^{\mathrm{a}}$ & $11.1^{\mathrm{a}}$ \\
\hline 150 & $245.9^{\mathrm{a}}$ & $17.3^{\mathrm{b}}$ & $117.3^{\mathrm{b}}$ & $9.2^{\mathrm{a}}$ \\
\hline \multicolumn{5}{|c|}{ MF Exposure [h] } \\
\hline 0 & $198.9^{\mathrm{b}}$ & $16.9^{\mathrm{b}}$ & $94.7^{\mathrm{b}}$ & $6.6^{\mathrm{b}}$ \\
\hline 6 & $243.3^{\mathrm{a}}$ & $21.7^{\mathrm{a}}$ & $119.6^{\mathrm{ab}}$ & $10.7^{\mathrm{a}}$ \\
\hline 12 & $247.7^{\mathrm{a}}$ & $19.4^{\mathrm{ab}}$ & $143.5^{\mathrm{a}}$ & $9.3^{\mathrm{a}}$ \\
\hline 24 & $242.6^{\mathrm{a}}$ & $19.5^{\mathrm{ab}}$ & $144.7^{\mathrm{a}}$ & $10.4^{\mathrm{a}}$ \\
\hline \multicolumn{5}{|l|}{ ANOVA } \\
\hline$\overline{\mathrm{NaCl}}$ & $* *$ & ns & $* *$ & $* *$ \\
\hline Intensity & $*$ & $* *$ & $* *$ & $*$ \\
\hline Duration & $*$ & $*$ & $*$ & $*$ \\
\hline $\mathrm{NaCl} \times$ Int & ns & ns & ns & ns \\
\hline $\mathrm{NaCl} \times$ Dur. & ns & ns & ns & ns \\
\hline Int. $\times$ Dur. & ns & ns & ns & $\mathrm{ns}$ \\
\hline $\mathrm{NaCl} \times$ Int.$\times$ Dur. & ns & ns & ns & ns \\
\hline
\end{tabular}

** and *: Significant at 0.01 and 0.05 levels, respectively; ns: Non-significant.

$\dagger$. Means separation by DMRT $(P \leq 0.05)$.

Plant biomass was significantly reduced under both $50 \mathrm{mM}(28.4 \mathrm{mg})$ and $100 \mathrm{mM} \mathrm{NaCl}$ stress $(24.6 \mathrm{mg})$ when compared to control treatment (33.1 mg). The highest plant biomass was found in $15 \mathrm{mT}$ MF treatments. However, no significant differences were observed between 6-h, 12-h and 24-h MF exposure durations (Table 3). Shoot:root DM was significantly increased by both $50 \mathrm{mM}$ and $100 \mathrm{mM} \mathrm{NaCl}$ stress, respectively. MF treatments significantly reduced shoot to root ratio, however, no significant differences were found between 15 and $150 \mathrm{mT}$ MF intensities. Shoot to root ratio of the 12-h and 24-h MF treatments was significantly lower when compared to the other treatments.
Salinity significantly reduced shoot length and the lowest plant height $(38.4 \mathrm{~mm})$ was found under $100 \mathrm{mM} \mathrm{NaCl}$ stress (Table 3). Shoot length of sweet corn seedlings significantly increased by MF treatments; however, no significant differences were observed between 15 and $150 \mathrm{mT}$ intensities and between the different MF exposure durations. Root length was significantly reduced under salt stress treatments. The highest root length $(84.8 \mathrm{~mm})$ was observed in $15 \mathrm{mT}$ MF treatments and the lowest value was found in non-magnetic treated plants $(50.1 \mathrm{~mm})$. Although MF exposure significantly increased root length of sweet corn, no significant differences were found between $6-\mathrm{h}$, 12-h and 24-h MF exposure durations. 
Table 3: Effects of salinity stress and magnetic treatments on fresh mass (FM) and dry mass (DM) of Zea mays var. saccharata seedling

\begin{tabular}{lllll}
\hline & $\begin{array}{l}\text { Biomass } \\
{[\mathrm{mg}]}\end{array}$ & $\begin{array}{l}\text { Shoot:Root } \\
{[\text { Dry mass] }}\end{array}$ & $\begin{array}{l}\text { Shoot Length } \\
{[\mathrm{mm}]}\end{array}$ & $\begin{array}{l}\text { Root Length } \\
{[\mathrm{mm}]}\end{array}$ \\
\hline $\mathrm{NaCl}[\mathrm{mM}]$ & $33.1^{\mathrm{a} \dagger}$ & $2.0^{\mathrm{b}}$ & $44.5^{\mathrm{a}}$ & $90.2^{\mathrm{a}}$ \\
0 & $28.4^{\mathrm{b}}$ & $2.2^{\mathrm{b}}$ & $41.2^{\mathrm{ab}}$ & $54.6^{\mathrm{b}}$ \\
50 & $24.6^{\mathrm{c}}$ & $4.3^{\mathrm{a}}$ & $38.4^{\mathrm{b}}$ & $55.7^{\mathrm{b}}$ \\
100 & $23.5^{\mathrm{c}}$ & $4.0^{\mathrm{a}}$ & & \\
$\mathrm{MF}$ Intensity $[\mathrm{mT}]$ & $35.9^{\mathrm{b}}$ & $50.1^{\mathrm{c}}$ \\
0 & $34.5^{\mathrm{a}}$ & $2.3^{\mathrm{b}}$ & $43.1^{\mathrm{a}}$ & $84.8^{\mathrm{a}}$ \\
15 & $26.5^{\mathrm{b}}$ & $2.3^{\mathrm{b}}$ & $44.4^{\mathrm{a}}$ & $69.9^{\mathrm{b}}$ \\
150 & $23.5^{\mathrm{b}}$ & $4.0^{\mathrm{a}}$ & & \\
$\mathrm{MF}$ Exposure $[\mathrm{h}]$ & & $35.9^{\mathrm{b}}$ & $50.1^{\mathrm{b}}$ \\
0 & $32.4^{\mathrm{a}}$ & $2.8^{\mathrm{ab}}$ & $43.4^{\mathrm{a}}$ & $75.4^{\mathrm{a}}$ \\
6 & $28.7^{\mathrm{a}}$ & $2.4^{\mathrm{b}}$ & $45.1^{\mathrm{a}}$ & $77.7^{\mathrm{a}}$ \\
12 & $29.9^{\mathrm{a}}$ & $2.0^{\mathrm{b}}$ & $42.6^{\mathrm{a}}$ & $75.5^{\mathrm{a}}$ \\
24 & & & & \\
\hline ANOVA & $* *$ & $* *$ & $* *$ & $* *$ \\
$\mathrm{NaCl}$ & $* *$ & $*$ & $*$ & $*$ \\
Intensity & $*$ & $*$ & $*$ & $*$ \\
Duration & $\mathrm{ns}$ & $\mathrm{ns}$ & $\mathrm{ns}$ & $\mathrm{ns}$ \\
$\mathrm{NaCl} \times$ Int. & $\mathrm{ns}$ & $\mathrm{ns}$ & $\mathrm{ns}$ & $\mathrm{ns}$ \\
$\mathrm{NaCl} \times$ Dur. & $\mathrm{ns}$ & $\mathrm{ns}$ & $\mathrm{ns}$ & $\mathrm{ns}$ \\
Int. $\times$ Dur. & $\mathrm{ns}$ & $\mathrm{ns}$ & $\mathrm{ns}$ & $\mathrm{ns}$ \\
$\mathrm{NaCl} \times$ Int. $\times$ Dur. & $\mathrm{ns}$ & &
\end{tabular}

** and *: Significant at 0.01 and 0.05 levels, respectively; ns: Non-significant.

$\dagger$. Means separation by DMRT $(P \leq 0.05)$.

Plant water content (PWC) was significantly reduced by $100 \mathrm{mM} \mathrm{NaCl}$ stress. MF exposure significantly increased PWC, however, no significant differences were observed between the MF intensities or between the different MF exposure durations (Table 4). Significant proline accumulation was observed in shoot under $100 \mathrm{mM} \mathrm{NaCl}$. MF exposure significantly prevented proline accumulation and the lowest proline concentration was found in 6-h magnetic exposure (Table 4).

Table 4: Effects of salinity stress and magnetic treatments on plant water content (PWC), membrane stability index (MSI) and concentration of proline, malondialdehyde (MDA) and $\mathrm{H}_{2} \mathrm{O}_{2}$ in shoot of Zea mays L. var. saccharata

\begin{tabular}{|c|c|c|c|c|c|}
\hline & $\begin{array}{l}\text { PWC } \\
{\left[\text { mg plant }^{-1}\right]}\end{array}$ & $\begin{array}{l}\text { Proline } \\
{\left[\mu \mathrm{mol} \mathrm{g}{ }^{-1} \mathrm{DM}\right]}\end{array}$ & $\begin{array}{l}\text { MTI } \\
{[\%]}\end{array}$ & \multicolumn{2}{|c|}{$\left[\mu \mathrm{mol} \mathrm{g} \mathrm{FM}^{-1}\right]$} \\
\hline \multicolumn{6}{|c|}{$\mathrm{NaCl}(\mathrm{mM})$} \\
\hline 0 & $359.3^{\mathrm{a \dagger}}$ & $186.3^{\mathrm{b}}$ & $81.7^{\mathrm{a}}$ & $2.99^{\mathrm{b}}$ & $0.100^{\mathrm{b}}$ \\
\hline 50 & $324.1^{\mathrm{ab}}$ & $186.6^{\mathrm{b}}$ & $77.2^{\mathrm{a}}$ & $3.11^{\mathrm{b}}$ & $0.118^{\mathrm{b}}$ \\
\hline 100 & $292.5^{\mathrm{b}}$ & $239.8^{\mathrm{a}}$ & $65.9^{\mathrm{b}}$ & $3.48^{\mathrm{a}}$ & $0.173^{\mathrm{a}}$ \\
\hline \multicolumn{6}{|c|}{ MF Intensity (mT) } \\
\hline 0 & $270.1^{\mathrm{b}}$ & $282.2^{\mathrm{a}}$ & $72.1^{\mathrm{b}}$ & 3.23 & 0.151 \\
\hline 15 & $368.5^{\mathrm{a}}$ & $177.8^{\mathrm{b}}$ & $78.7^{\mathrm{a}}$ & 3.21 & 0.120 \\
\hline 150 & $336.7^{\mathrm{a}}$ & $184.0^{\mathrm{b}}$ & $80.5^{\mathrm{a}}$ & 3.44 & 0.123 \\
\hline \multicolumn{6}{|c|}{ MF Exposure (h) } \\
\hline 0 & $270.1^{\mathrm{b}}$ & $282.2^{\mathrm{a}}$ & $71.9^{\mathrm{c}}$ & 3.23 & $0.141^{\mathrm{a}}$ \\
\hline 6 & $330.5^{\mathrm{a}}$ & $157.3^{\mathrm{c}}$ & $78.1^{\mathrm{b}}$ & 3.12 & $0.102^{b}$ \\
\hline 12 & $362.5^{\mathrm{a}}$ & $203.4^{\mathrm{b}}$ & $80.1^{\mathrm{a}}$ & 3.13 & $0.118^{\mathrm{b}}$ \\
\hline 24 & $327.4^{\mathrm{a}}$ & $182.1^{\mathrm{bc}}$ & $70.9^{c}$ & 3.30 & $0.158^{\mathrm{a}}$ \\
\hline
\end{tabular}




\begin{tabular}{llllll}
\hline $\mathrm{ANOVA}$ & & & & & \\
$\mathrm{NaCl}$ & $* *$ & $* *$ & $* *$ & $* *$ & $* *$ \\
Intensity & $*$ & $*$ & $*$ & $\mathrm{~ns}$ & $\mathrm{~ns}$ \\
Duration & $*$ & $*$ & $\mathrm{~ns}$ & $\mathrm{~ns}$ & $*$ \\
$\mathrm{NaCl} \times$ Int. & $\mathrm{ns}$ & $* *$ & $\mathrm{~ns}$ & $\mathrm{~ns}$ \\
$\mathrm{NaCl} \times$ Dur. & $\mathrm{ns}$ & $\mathrm{ns}$ & $\mathrm{ns}$ & $\mathrm{ns}$ & $\mathrm{ns}$ \\
$\mathrm{Int} \times$ Dur. & $\mathrm{ns}$ & $\mathrm{ns}$ & $\mathrm{ns}$ & $\mathrm{ns}$ & $\mathrm{ns}$ \\
$\mathrm{NaCl} \times$ Int. $\times$ Dur. & $\mathrm{ns}$ & $\mathrm{ns}$ & $\mathrm{ns}$ & \\
\hline
\end{tabular}

$* *$ and *: Significant at 0.01 and 0.05 levels, respectively; ns: Non-significant.

$\dagger$. Means separation by DMRT $(P \leq 0.05)$.

The interaction of MF exposure duration and $\mathrm{NaCl}$ concentration significantly affected proline concentration in shoot (Figure 3). The interaction effect indicated that magnetic exposure for 6 or 12 hours reduced proline concentration in the plant shoot to the control level, however, a significant increase in proline concentration was observed in the seedling exposed to 24-h MF treatment in combination with salt stress treatments. A significant positive correlation was observed between PWC and proline concentration in the leaves (Figure 4).

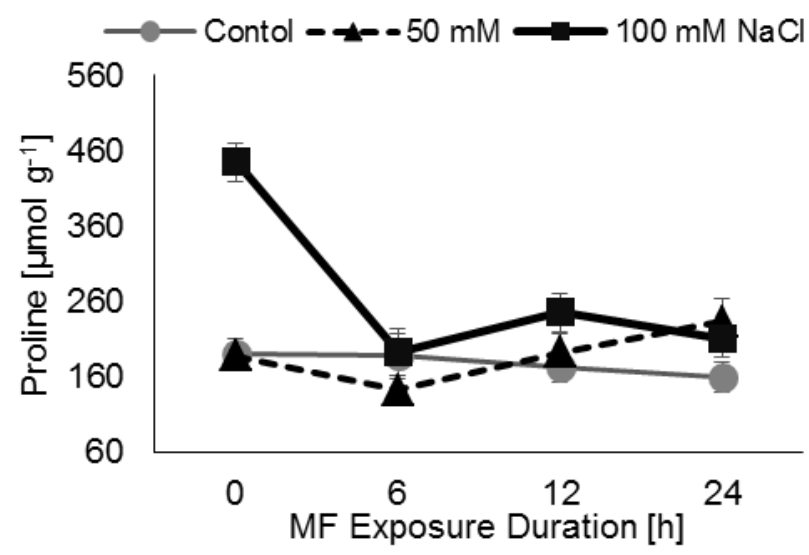

Figure 3: The interaction effect of magnetic field exposure duration and $\mathrm{NaCl}$ concentration in medium on concentration of proline in shoot of Zea mays var. saccharata (Data are means \pm SEM of four independent samples)

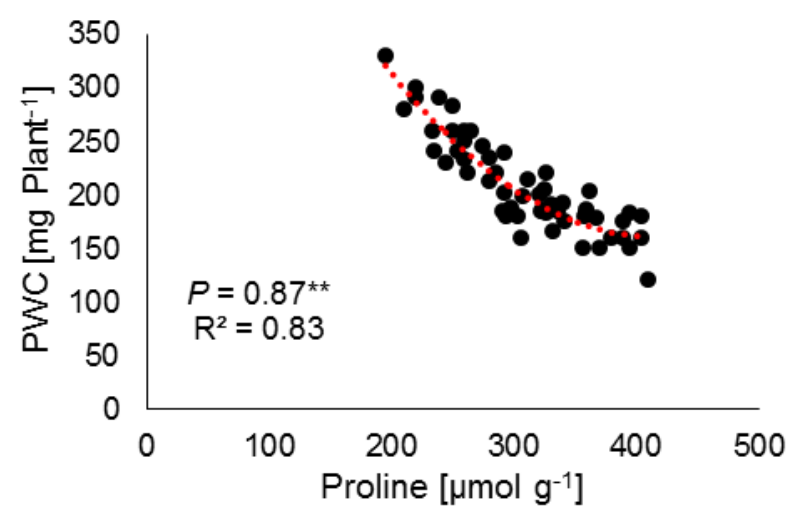

Figure 4: Correlation between plant water content (PWC) and proline concentration in the shoot of Zea mays var. saccharata 
Application of $100 \mathrm{mM} \mathrm{NaCl}$ significantly reduced MTI in shoot by $15.8 \%$ (Table 4). MF pretreatments significantly improved MTI as the highest MTI was obtained in 12-h MF exposure $(80 \%)$. MTI was significantly affected by the interaction effect of salt stress and magnetic exposure duration (Figure 5). The interaction effect indicated that although MF pretreatment of seed enhanced MTI in the seedlings under salt stress, by increasing MF exposure up to 24 hours a significant reduction in MTI was observed under $100 \mathrm{mM} \mathrm{NaCl}$ stress. In this order, the 6-h treatment enhanced plasma membrane thermostability of salt affected plants up to the control level. A significant accumulation of $\mathrm{H}_{2} \mathrm{O}_{2}$ in plant tissues was observed in $100 \mathrm{mM} \mathrm{NaCl}$ treatment (Table 4). A significant interaction effect of $\mathrm{NaCl}$ level and MF exposure duration on $\mathrm{H}_{2} \mathrm{O}_{2}$ was found, which indicated that magnetic exposure induced $\mathrm{H}_{2} \mathrm{O}_{2}$ accumulation in plant of non-saline treatment. However, exposing the seeds for 6 or 12 hours to $\mathrm{MF}$ reduced $\mathrm{H}_{2} \mathrm{O}_{2}$ accumulation in the plants under salt stress, although the trend was not statistically significant. On the other hand, MF treatment for 24 hours did not reduce $\mathrm{H}_{2} \mathrm{O}_{2}$ content under $100 \mathrm{mM} \mathrm{NaCl}$ stress (Figure 5). A positive correlation was found between $\mathrm{H}_{2} \mathrm{O}_{2}$ content and plasma membrane thermostability index (Figure 6).

Accumulation of MDA was observed in the plants under salt stress (Table 4), which in parallel MTI significantly reduced (Figure 6). The highest MDA concentration was detected in plants under $100 \mathrm{mM} \mathrm{NaCl}$ treatment. Magnetic exposure of seeds for 6 and 12 hours significantly reduced MDA content in plant and no significant difference was detected between the week and the strong magnetic fields.
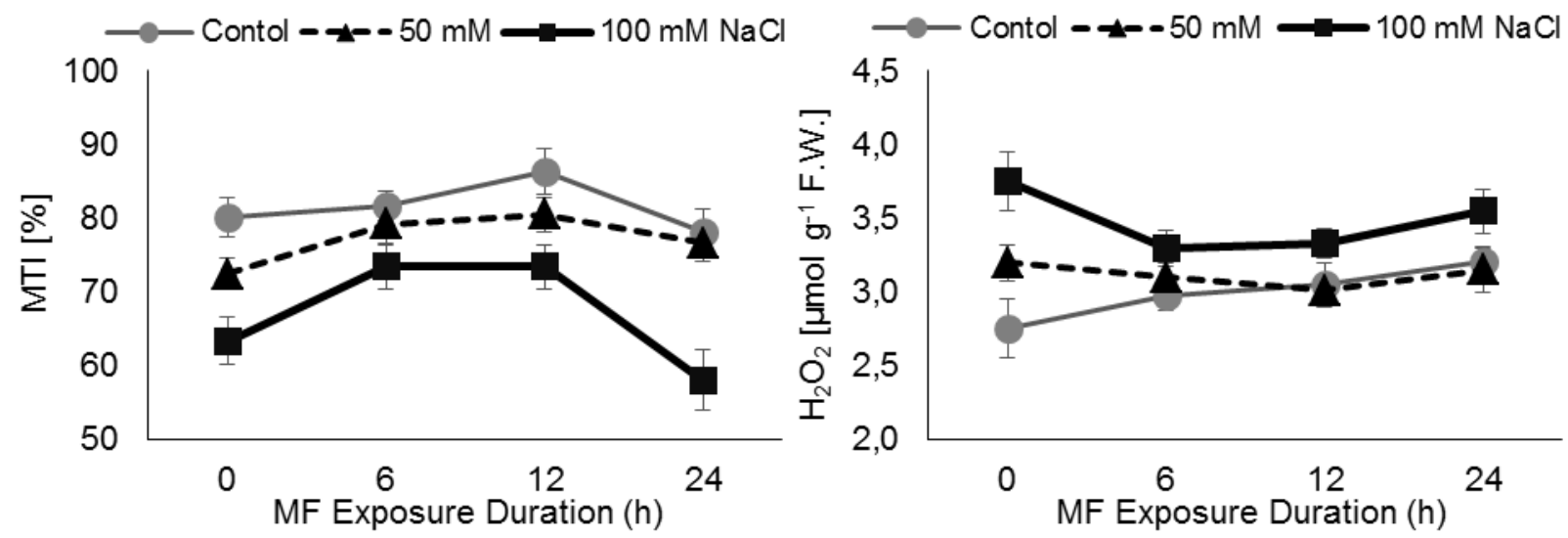

Figure 5: The interaction effect of magnetic field exposure duration and $\mathrm{NaCl}$ concentration in medium on plasma membrane thermostability index (MTI) in shoot of Zea mays var. saccharata (Data are means \pm SEM of four independent samples)
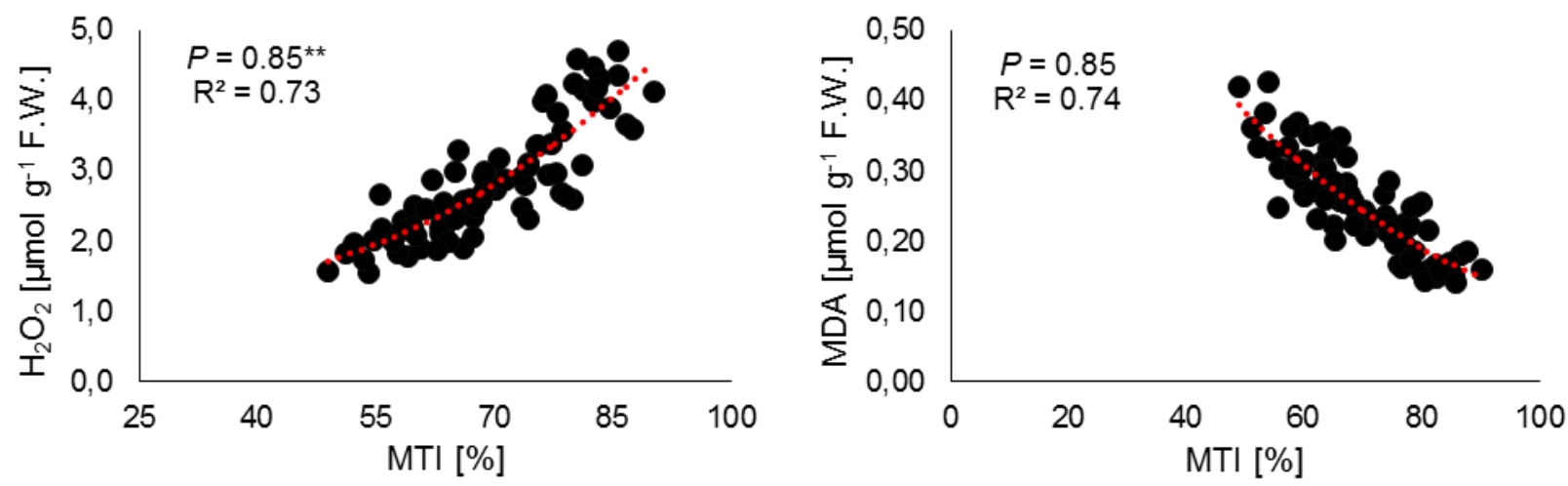

Figure 6: Correlation between membrane stability index (MSI) and concentration of malondialdehyde (MDA) and $\mathrm{H}_{2} \mathrm{O}_{2}$ in the shoot of Zea mays var. saccharata 


\section{DISCUSSION}

The model plant which was used for this experiment, Z. mays var. saccharata, is a salt sensitive species (Chinnusamy et al., 2005; ChaUm and Kirdmanee, 2011). In recent years, improving salt tolerance of this species has attained more attention in breeding programs (Bänziger et al., 2006; Cha-Um and Kirdmanee, 2011). In the current study adverse effects of salt stress were observed on the plant during seed germination and early growth stages. Ashraf and Rauf (2001) also reported the adverse effects of $\mathrm{NaCl}$ stress on sweet corn during seed germination and seedling growth stages. It has not been clarified which component of salt stress mainly affects plant during seed germination. Our results indicated that salt stress did not affect sweet corn seed germination during early 24 hours after salt treatment, however, the adverse effects of $100 \mathrm{mM}$ $\mathrm{NaCl}$ stress became evident after $48 \mathrm{~h}$. The detrimental effects of salinity were increased by time, as the final seed germination was equal in 50 and $100 \mathrm{mM} \mathrm{NaCl}$ treatments. Similar results were found in the case of germination rate indices. The results suggest that during the early stages, seed germination rate is inhibited through reducing imbibition due to osmotic impact of salt stress. However, with increasing the contact between salts and the seeds over time, the germination percentage is limited due to ion toxicity. A recent report by Lin et al. (2011) confirms this conclusion.

Ramoliya et al. (2006) stated that salinity suppresses shoot growth more than root growth. Similar results are evident in Ashraf and Rauf (2001) research on sweet corn. However, in the current study, salt stress did not affect biomass accumulation in plant shoot. Accordingly, the reductions in shoot FM and elongation were due to water deficit under salt stress. Cha-Um and Kirdmanee (2011) stated that limitation of water availability in growing medium due to reduced osmotic potential is detrimental to sweet corn growth under salt stress. In the current study, the reduced PWC which was observed under salt stress confirms this finding. Root showed more susceptibility to salt stress as biomass accumulation in root was reduced to less than $25 \%$ when compared to shoots under $100 \mathrm{mM} \mathrm{NaCl}$ stress. Therefore, the reduced biomass of the seedlings under salt stress was mainly due to the inhibition of root growth. The reduction in biomass accumulation in plant organs is a result of slower growth and development due to osmotic effect of salinity (Shani and Ben-Gal, 2005) and a decline in net photosynthesis (Arfan et al., 2007). Moreover, enhanced respiration of cell under this situation (Jacoby et al., 2011) and injuries to cells in growing points result in reduction in overall sink capacity and plant growth (Moradi and Ismail, 2007). The detrimental effects of $\mathrm{NaCl}$ stress on sweet corn growth in terms of dry matter production and water absorption was previously shown by other authors (Shenker et al., 2003).

Different types of pre-sawing treatments can be used for improving seed germination and seedling establishment under abiotic stress conditions (Ashraf and Rauf, 2001; Iqbal and Ashraf, 2010). Several reports have showed the positive effects of magnetic treatments on seed germination and plant growth (Aladjadjiyan, 2002; Podlesni et al., 2004; Yao et al., 2005; Fl'orez et al., 2007). However, reports on evaluating the performance of MFprimed plants under abiotic stress are scarce. The results of the current study indicated that magnetic priming treatments enhance seed germination and growth of sweet corn seedling under non-saline and salt stress conditions. Yao et al. (2005) and Fl'orez et al. (2007) stated that increasing MF intensity enhances seed germination and plant growth. In the current study, although the stronger MF significantly reduced MGT and time required for obtaining the final germination percentage, increasing MF intensity did not affect the final germination percentage. These effects were mainly due to increasing germination percentage till $24 \mathrm{~h}$ after exposure and such effects were gradually reduced afterward. Hence, it can be concluded that increasing MF intensity mainly improves rate of germination. This positive effect appears not to be durable and is vanished over time.

The results revealed that enhancement of water absorption after MF exposure was a major factor in the mechanism of improvement of seed germination and seedling growth under salt stress. Other studies also showed that seeds or plants exposed to MF absorb more moisture (Garcia and Arza, 2001; Karimi et al., 2012). The mechanism 
of MF treatment on promoting seed imbibition is not completely known, but it may be a result of the changes in intracellular levels of $\mathrm{Ca}^{++}$and other ionic current density across cellular membrane which increase osmotic pressure and cellular membrane capacity to absorb more water (Dhawi and Al-Khayri, 2011). In a previous study, we found that MF exposure improves osmotic stress tolerance of plant by enhancing osmotic adjustment capability and improving water availability to plant (Karimi et al., 2012). Moreover, an increase in activity of enzymes after MF exposure can be involved in higher seed germination and vigor under salt stress (Vashisth and Nagarajan, 2010). Atak et al. (2007) reported that the peroxidase activity increases as plants passes through MF. Moreover, Sahebjamei et al. (2009) showed that activity of superoxide dismutase also enhances in cell after MF exposure. Enhancement of ROS scavenger enzymes is critical for salt tolerance of plant.

In the current study, a significant increase in concentration of proline in the root of non-primed plants was observed under salt stress. The accumulation of proline in sweet corn in response to salt stress was reported in previous studies (ChaUm and Kirdmanee, 2011). Proline accumulation is a widespread response of plants to environmental stresses (Anjum, 2008), which is shown to be involved in defense of plants against salinity and osmotic stress (Asraf, 2004; Karimi et al., 2012). Accumulation of ions in tissues and/or tissue dehydration under salt stress may trigger proline accumulation. In this study, proline accumulation in shoot was in parallel with reduction of PWC. The results revealed that water deficit is the primarily responsible for proline accumulation in plant under salt stress. The effects of MF treatments on promoting PWC and preventing proline accumulation confirm this hypothesis. Another possible conclusion is that the accumulation of proline may be regarded as a good index of salt stress pressure on this species. These conclusions are in accordance with Cha-Um and Kirdmanee (2011) that showed proline accumulation in salt sensitive maize cultivar in response to salt stress is significantly higher than the salt tolerant genotype. Similar results also have been reported in other crops such as rice and sorghum, grown under salt stress (de Lacerda, et al., 2005; Demiral and Türkan, 2005).
Although MF exposure enhanced sweet corn germination capacity, some trends in reducing seed germination and seed germination rate were observed by increasing MF exposure duration up to $24 \mathrm{~h}$. Generally, seed germination and seedling growth after 24-h exposure to MF were less than the other MF treatments. On the other hand, MF intensity $15 \mathrm{mT}$ was also more effective than 150 $\mathrm{mT}$ in improving seedling growth parameters. Carbonel et al. (2000) and Vashisth and Nagarajan (2010) also reported that strong magnetic fields may adversely affect seed germination and plant growth. The mechanism of such detrimental effects of exposing to strong magnetic fields or prolonged MF treatments are unknown; however, MF may induce mutation and DNA damage in plant (Ager and Radul, 1992) and other organisms (Zmyslony et al., 2000). Robison et al. (2002) also showed that electromagnetic treatments decrease DNA repair rate. On the other hand, lower seeds germination and seedlings growth can be related to overproduction of hydrogen peroxide in plant and increased lipid oxidation after exposing seeds to stronger MF or prolonged MF treatments (Podleoeny et al., 2005). Our results confirmed the accumulation of $\mathrm{H}_{2} \mathrm{O}_{2}$ in plant shoot after magnetic exposure. However, the increase in $\mathrm{H}_{2} \mathrm{O}_{2}$ concentration in plant was positively correlated with enhancement of MTI. Recent studies have shown that reactive oxygen species (ROS) such as $\mathrm{H}_{2} \mathrm{O}_{2}$ at low doses act as major signals and secondary messengers in regulating plant acclimation responses to environmental stresses (Foyer and Noctor, 2005). A molecular signal system by sensing small changes in $\mathrm{H}_{2} \mathrm{O}_{2}$ levels controls gene expression to activate cell responses to environmental stresses (Vanderauwera et al., 2005). Thus plant by sensing redox changes in cell becomes prepared to the particular needs of abiotic stress situations (Gechev et al., 2002). In this order, Vanderauwera et al. (2005) identified 20 genes, including the transcription factor DREB2A, which were induced in response to $\mathrm{H}_{2} \mathrm{O}_{2}$ and abiotic stress situations. DREB2A is a key regulator of cell responses to dehydration (Yoshida et al., 2014). Our results revealed that magnetic exposure activates plant defense system by inducing $\mathrm{H}_{2} \mathrm{O}_{2}$ accumulation in cell, which results in faster and stronger response to abiotic stress. However, overproduction of $\mathrm{H}_{2} \mathrm{O}_{2}$ was observed in the 24-h exposure treatment that explains the adverse 
effects of prolonged magnetic exposure on seed germination and plant growth.

According to Ashraf and Rauf (2001), accumulation of high levels of $\mathrm{Na}^{+}$and $\mathrm{Cl}^{-}$in sweet corn probably trigger the injuries to the plasma membrane by affecting ion homeostasis in cell under salt stress. Physiological resonance causes ROS overproduction and induces lipid peroxidation in cell under this condition, which eventually leads to plasma membrane injuries and malfunction (Foyer and Shigeoka, 2011). In the current study, plasma membrane thermostability significantly reduced under $100 \mathrm{mM} \mathrm{NaCl}$ stress and in seedlings of 24-h MF treatment. Accumulation of MDA, the by-product of nonenzymatic lipid peroxidation, in parallel with overproduction of $\mathrm{H}_{2} \mathrm{O}_{2}$ and loss of MTI confirmed peroxidation of membrane lipids under salt stress. These observations suggest that although MF treatments may reduce oxidative pressure on plant under salt stress, accumulation of high doses of
$\mathrm{H}_{2} \mathrm{O}_{2}$ after prolonged MF exposure may adversely affect plant performance under severe abiotic stress.

In conclusion, this study showed that the positive effects of MF on germination and early growth of plant depend on the intensity and the duration of MF exposure. The results revealed that stronger MF exposure enhances rate of seed germination, however, using stronger MF or increasing MF exposure duration do not necessarily exert positive effects on final seed germination percentage and plant growth. MF exposure was found to improve plant water absorption capability and induce $\mathrm{H}_{2} \mathrm{O}_{2}$ signaling in cells, priming plant to deal with salt stress. Therefore, magnetic pretreatment for a short duration was suggested as an applicable approach to improve seed germination and seedling performance under salt stress. Such treatments are simple, cheap, and environmental friendly; however, the results suggested that this technique should be optimized for each species.

\section{REFERENCES}

Ager, D. D., Radul, J. A. (1992). Effect of $60-\mathrm{Hz}$ magnetic fields on ultraviolet light-induced mutation and mitotic recombination in Saccharomyces cerevisiae. Mutation Research Letters, 283(4), 279-286. doi:10.1016/01657992(92)90060-U

Aladjadjiyan A. (2002). Study of the influence of magnetic field on some biological characteristics of Zea mays, Journal of Central European Agriculture, 3(2), 89-94.

Anjum, M. A. (2008). Effect of $\mathrm{NaCl}$ concentrations in irrigation water on growth and polyamine metabolism in two citrus rootstocks with different levels of salinity tolerance. Acta Physiologiae Plantarum, 30(1), 43-52. doi:10.1007/s11738-0070089-3

Arora, R., Pitchay, D. S., Bearce, B. C. (1998). Water-stress-induced heat tolerance in geranium leaf tissues: A possible linkage through stress proteins?. Physiologia Plantarum, 103(1), 24-34. doi:10.1034/j.1399-3054.1998.1030104.x

Arfan, M., Athar, H. R., Ashraf, M. (2007). Does exogenous application of salicylic acid through the rooting medium modulate growth and photosynthetic capacity in two differently adapted spring wheat cultivars under salt stress?. Journal of
Plant Physiology, 164(6), 685-694. doi:10.1016/j.jplph.2006.05.010

Ashraf, M. (2004). Some important physiological selection criteria for salt tolerance in plants. FloraMorphology, Distribution, Functional Ecology of Plants, 199(5), 361-376. doi:10.1078/0367-253000165

Ashraf, M., Rauf, H. (2001). Inducing salt tolerance in maize (Zea mays L.) through seed priming with chloride salts: Growth and ion transport at early growth stages. Acta Physiologiae Plantarum, 23(4), 407-414. doi:10.1007/s11738-001-0050-9

Atak, Ç., Çelik, Ö., Olgun, A., Alikamanoğlu, S., Rzakoulieva, A. (2007). Effect of magnetic field on peroxidase activities of soybean tissue culture. Biotechnology \& Biotechnological Equipment, 21(2),

166-171. doi:10.1080/13102818.2007.10817438

Bänziger, M., Setimela, P. S., Hodson, D., Vivek, B. (2006). Breeding for improved abiotic stress tolerance in maize adapted to southern Africa. Agricultural Water Management, 80(1), 212-224. doi:10.1016/j.agwat.2005.07.014

Bates, L. S., Waldren, R. P., Teare, I. D. (1973). Rapid determination of free proline for water-stress 
studies. Plant and soil, 39(1), 205-207. doi:10.1007/BF00018060

Cakmak T., Dumlupinar R., Erdal S. (2010). Acceleration of germination and early growth of wheat and bean seedlings grown under various magnetic field and osmotic conditions, Bioelectromagnetics, 31(2), 120-129. doi:10.1002/bem.20537

Cha-Um, S. Kirdmanee, C. (2009). Effect of salt stress on proline accumulation, photosynthetic ability and growth characters in two maize cultivars. Pakistan Journal of Botany, 41(1), 87-98.

Chinnusamy, V., Jagendorf, A., Zhu, J. K. (2005). Understanding and improving salt tolerance in plants. Crop Science, 45(2), 437-448. doi:10.2135/cropsci2005.0437

Cuartero, J., Bolarin, M. C., Asins, M. J., Moreno, V. (2006). Increasing salt tolerance in the tomato. Journal of Experimental Botany, 57(5), 1045-1058. doi:10.1093/jxb/erj102

de Lacerda, C. F., Cambraia, J., Oliva, M. A., Ruiz, H. A. (2005). Changes in growth and in solute concentrations in sorghum leaves and roots during salt stress recovery. Environmental and Experimental Botany, 54(1), 69-76. doi:10.1016/j.envexpbot.2004.06.004

Demiral, T., Türkan, I. (2005). Comparative lipid peroxidation, antioxidant defense systems and proline content in roots of two rice cultivars differing in salt tolerance. Environmental and Experimental Botany, 53(3), 247-257. doi:10.1016/j.envexpbot.2004.03.017

Dhawi, F., Al-Khayri, J. M. (2011). Magnetic field induced biochemical and growth changes in date palm seedlings. In S. M. Jain, J. M. Al-Khayri \& D. V. Johnson Date Palm Biotechnology (pp. 287309). Netherlands, Springer. doi:10.1007/978-94007-1318-5_15

Florez, M., Carbonell, M. V., Martínez, E. (2007). Exposure of maize seeds to stationary magnetic fields: Effects on germination and early growth. Environmental and Experimental Botany, 59(1), 68-75. doi:10.1016/j.envexpbot.2005.10.006

Foyer, C. H., Noctor, G. (2005). Oxidant and antioxidant signalling in plants: a re-evaluation of the concept of oxidative stress in a physiological context. Plant, Cell \& Environment, 28(8), 10561071. doi:10.1111/j.1365-3040.2005.01327.x

Foyer, C. H., Shigeoka, S. (2011). Understanding oxidative stress and antioxidant functions to enhance photosynthesis. Plant Physiology, 155(1), 93-100. doi:10.1104/pp.110.166181
Garcia R. F., Arza P. L. (2001). Influence of a stationary magnetic field on water relations in lettuce seeds Part I: theoretical considerations, Bioelectromagnetics, $\quad 22, \quad 589-595$. doi:10.1002/bem. 88

Gechev, T. S., Gadjev, I., Van Breusegem, F., Inzé, D., Dukiandjiev, S., Toneva, V., Minkov, I. (2002). Hydrogen peroxide protects tobacco from oxidative stress by inducing a set of antioxidant enzymes. Cellular and Molecular Life Sciences CMLS, 59(4), 708-714. doi:10.1007/s00018-002-8459-x

Heath, R. L., Packer, L. (1968). Photoperoxidation in isolated chloroplasts: I. Kinetics and stoichiometry of fatty acid peroxidation. Archives of Biochemistry and Biophysics, 125(1), 189-198. doi:10.1016/0003-9861(68)90654-1

Iqbal, M., Ashraf, M. (2010). Changes in hormonal balance: a possible mechanism of pre-sowing chilling-induced salt tolerance in spring wheat. Journal of Agronomy and Crop Science, 196(6), 440-454. doi:10.1111/j.1439-037X.2010.00434.x

ISTA, (2004). International rules for seed testing, International seed test association. Zurich Switzerland.

Jacoby, R. P., Taylor, N. L., Millar, A. H. (2011). The role of mitochondrial respiration in salinity tolerance. Trends in Plant Science, 16(11), 614623. doi:10.1016/j.tplants.2011.08.002

Karimi, S., Hojati, S., Eshghi, S., Moghaddam, R. N., Jandoust, S. (2012). Magnetic exposure improves tolerance of fig 'Sabz' explants to drought stress induced in vitro. Scientia Horticulturae, 137, 9599. doi:10.1016/j.scienta.2012.01.018

Lin, J., Wang, J., Li, X., Zhang, Y., Xu, Q., Mu, C. (2011). Effects of saline and alkaline stresses in varying temperature regimes on seed germination of Leymus chinensis from the Songnen Grassland of China. Grass and Forage Science, 66(4), 578-584. doi:10.1111/j.1365-2494.2011.00818.x

Moradi, F. Ismail, A. M. (2007). Responses of photosynthesis, chlorophyll fluorescence and ROSscavenging systems to salt stress during seedling and reproductive stages in rice. Annals of Botany, 99(6), 1161-1173. doi:10.1093/aob/mcm052

Piacentini, M. P., Fraternale, D., Piatti, E., Ricci, D., Vetrano, F., Dachà, M., \& Accorsi, A. (2001). Senescence delay and change of antioxidant enzyme levels in Cucumis sativus L. etiolated seedlings by ELF magnetic fields. Plant Science, 161(1), 45-53. doi:10.1016/S0168-9452(01)003806 
Podleœny, J., Misiak, L., Podleœna, A., Pietruszewski, S. (2005). Concentration of free radicals in pea seeds after pre-sowing treatment with magnetic field. International Agrophysics, 19(3), 243-249.

Podleoeny, J., Pietruszewski, S., Podleoena, A. (2004). Efficiency of the magnetic treatment of broad bean seeds cultivated under experimental plot conditions. International Agrophysics, 18, 65-71.

Radhakrishnan, R., Kumari, B. D. R. (2012). Pulsed magnetic field: a contemporary approach offers to enhance plant growth and yield of soybean. Plant Physiology and Biochemistry, 51, 139-144. doi:10.1016/j.plaphy.2011.10.017

Ramoliya, P. J., Patel, H. M., Joshi, J. B., Pandey, A. N. (2006). Effect of salinization of soil on growth and nutrient accumulation in seedlings of Prosopis cineraria. Journal of Plant Nutrition, 29(2), 283303. doi:10.1080/01904160500476806

Robison, J. G., Pendleton, A. R., Monson, K. O., Murray, B. K., O'Neill, K. L. (2002). Decreased DNA repair rates and protection from heat induced apoptosis mediated by electromagnetic field exposure. Bioelectromagnetics, 23(2), 106-112. doi:10.1002/bem.103

Ružič, R., Jerman, I. (2002). Weak magnetic field decreases heat stress in cress seedlings. Electromagnetic Biology and Medicine, 21(1), 6980. doi:10.1081/JBC-120003112

Sahebjamei, H., Abdolmaleki, P., Ghanati, F. (2007). Effects of magnetic field on the antioxidant enzyme activities of suspension-cultured tobacco cells. Bioelectromagnetics, 28(1), 42-47. doi:10.1002/bem.20262

Shani, U., Ben-Gal, A. (2005). Long-term response of grapevines to salinity: osmotic effects and ion toxicity. American Journal of Enology and Viticulture, 56,148-154.

Shenker, M., Ben-Gal, A., Shani, U. (2003). Sweet corn response to combined nitrogen and salinity environmental stresses. Plant and Soil, 256(1), 139147. doi:10.1023/A:1026274015858

Stange, B. C., Rowland, R. E., Rapley, B. I., Podd, J. V. (2002). ELF magnetic fields increase amino acid uptake into Vicia faba L. roots and alter ion movement across the plasma membrane. Bioelectromagnetics, 23(5), 347-354. doi:10.1002/bem.10026

Vanderauwera, S., Zimmermann, P., Rombauts, S., Vandenabeele, S., Langebartels, C., Gruissem, W., Inzé, D., Van Breusegem, F. (2005). Genome-wide analysis of hydrogen peroxide-regulated gene expression in Arabidopsis reveals a high lightinduced transcriptional cluster involved in anthocyanin biosynthesis. Plant Physiology, 139(2), 806-821. doi:10.1104/pp.105.065896

Vashisth, A., Nagarajan, S. (2010). Effect on germination and early growth characteristics in sunflower (Helianthus annuus) seeds exposed to static magnetic field. Journal of Plant Physiology, 167(2), 149-156. doi:10.1016/j.jplph.2009.08.011

Velikova, V., Yordanov, I., Edreva, A. (2000). Oxidative stress and some antioxidant systems in acid rain-treated bean plants: Protective role of exogenous polyamines. Plant Science, 151(1), 5966. doi:10.1016/S0168-9452(99)00197-1

Xi G., Fu Z. D., Ling J. (1994). Change of peroxidase activity in wheat seedlings induced by magnetic field and its response under dehydration condition, Acta Botanica Sinica, 36, 113-118.

Yao, Y., Li, Y., Yang, Y., Li, C. (2005). Effect of seed pretreatment by magnetic field on the sensitivity of cucumber (Cucumis sativus) seedlings to ultraviolet-B radiation. Environmental and Experimental Botany, 54(3), 286-294. doi:10.1016/j.envexpbot.2004.09.006

Yoshida, T., Mogami, J., Yamaguchi-Shinozaki, K. (2014). ABA-dependent and ABA-independent signaling in response to osmotic stress in plants. Current Opinion in Plant Biology, 21, 133-139. doi:10.1016/j.pbi.2014.07.009

Zmyslony, M., Palus, J., Jajte, J., Dziubaltowska, E., Rajkowska, E. (2000). DNA damage in rat lymphocytes treated in vitro with iron cations and exposed to $7 \mathrm{mT}$ magnetic fields (static or $50 \mathrm{HZ}$ ). Mutation Research, 453, 89-96. doi:10.1016/S0027-5107(00)00094-4 